\title{
INVESTIGATION OF EDUCATION \\ FACULTY STUDENTS' VIEWS ON DISTANCE EDUCATION: THE EXAMPLE OF INONU UNIVERSITY, TURKEY ${ }^{i}$
}

\author{
Fatih Kaya ${ }^{1}$, \\ Ramazan Özkul', \\ Metin Kirbaçii \\ İ̇önü University, \\ Faculty of Education, \\ Turkey \\ ${ }^{2}$ Ministry of National Education, \\ R\&D Unit, \\ Turkey \\ 3̇̇nönü University, \\ Faculty of Education, \\ Turkey
}

\begin{abstract}
:
In the last century we live in, technological developments are advancing faster than ever, and the world is changing irresistibly. With the Covid-19 epidemic, this change has moved to a very different dimension. Especially today, the pandemic conditions of the whole world have increased the importance of distance education by directing education to the digital field. The aim of this study is to examine the views of education faculty students towards distance education. This research, which aims to examine the views of education faculty students on distance education, is a quantitative method and causal comparison model research. The study population of the research consists of Inönü University Faculty of Education students. The sample of the study consisted of 584 participants determined by the random stratified sampling method from the population. While determining the stratum, the gender variable was taken as a basis. The data of the research were collected with the "Distance Education Evaluation Scale". The obtained data were subjected to independent groups t-test, one-way ANOVA and descriptive statistics tests. According to the research findings, students preferred distance education to face-to-face education. In addition, in terms of the efficiency of the distance education process, it is important to use computers and students to have their own rooms.
\end{abstract}

Keywords: faculty of education, student, distance education

\footnotetext{
i EĞİTIM FAKÜLTESI ÖĞRENCILERININ UZAKTAN EĞITIIME YÖNELIKK GÖRÜŞLERININ İNCELENMESİ: İNÖNÜ ÜNIVERSITESI ÖRNEĞİ

ii Correspondence: email fatih.kaya@inonu.edu.tr, metin.kirbac@inonu.edu.tr
} 


\section{Özet:}

İçinde bulunduğumuz son yüz yılda teknolojik gelişmeler her zamankinden daha hızlı ilerlemekte ve dünya karşı konulamaz bir biçimde değişime uğramaktadır. Covid-19 salgını ile birlikte bu değişim çok farklı bir boyuta taşınmıştır. Özellikle bugün, bütün dünyanın içinde bulunduğu pandemi koşulları, eğitimi tamamen dijital alana yönlendirerek uzaktan eğitimin önemini daha da arttırmıştır. Bu çalışmanın amacı eğitim fakültesi öğrencilerinin uzaktan eğitime yönelik görüşlerinin incelenmesidir. Eğitim fakültesi öğrencilerinin uzaktan eğitime ilişkin görüşlerini incelemeyi amaçlayan bu araştırma nicel yöntemli ve nedensel karşılaştırma modelli bir araştırmadır. Araştırmanın çalışma evrenini İnönü Üniversitesi Eğitim Fakültesi Öğrencileri oluşturmaktadır. Araştırmanın örneklemi ise evrenden seçkisiz tabakalı örnekleme yöntemi ile belirlenen 584 katılımcı oluşturmuştur. Tabaka belirlenirken cinsiyet değişkeni kriter olarak alınmıştır. Araştırmanın verileri "Uzaktan Eğitim Değerlendirme Ölçeği" ile toplanmıştır. Elde edilen veriler, bağımsız gruplar t-testi, tek yönlü ANOVA ve betimsel istatistik testlerine tabi tutulmuştur. Araştırma bulgularına göre öğrenciler uzaktan eğitimi, yüz yüze eğitime tercih etmişlerdir. Ayrıca uzaktan eğitim sürecinin verimliliği açısından bilgisayar kullanımının ve öğrencilerin kendilerine ait odalarının olmasının önemli olduğu öne çıkan sonuçlardır.

Anahtar kelimeler: eğitim fakültesi, öğrenci, uzaktan eğitim

\section{Introduction}

The century we live in today is one of the remarkable periods in which great changes were experienced in many scientific, social, economic and cultural fields, and the greatest wars, transformations and developments in history took place. Especially the first twenty years of the current century witnessed a period in which technological progress experienced its golden age alongside all other developments. So much so that these developments have progressed in a dizzying way and the world has come under the influence of global technologies in a short period of about twenty years. This global impact has turned the world into a small town, not only in the field of technology, but also in education, art, culture, sports and economic fields, especially in global communication.

The expansion of global communication networks with technological developments has undoubtedly shown its greatest impact in the field of education. As a matter of fact, the spread of communication networks between countries and individuals, in the field of education; It has created a global understanding of education by accelerating the circulation of information resources, ideas and products. Developments in the field of education have not been limited to the circulation of resources and ideas; There have been radical changes in many areas from traditional education methods to teacher-student relations, from the philosophical foundations of education to educational theories. At this point, one of the subjects in which the transformation in education has 
been experienced together with the technological developments has been the educational environments, which are among the basic elements of education. Since the early ages, education has continued in places where students and teachers physically share the same environment (school, classroom, home, library, etc.). However, with the unstoppable involvement of global communication in our lives, the perception of distance between people and countries has been broken to a large extent by means of communication tools (internet, TV, social media, etc.), and the perception of time and space has changed. Education planners, who could not remain unconcerned to this rapid change, created more modern, virtual education environments by integrating mass media into education environments in the process. Among the virtual education environments, the most popular one in today is the distance education applications, in which individuals in different places are involved in education at the same time by using technological devices. Distance education applications, which have an adventure of about half a century, are gaining more and more place in education activities day by day, depending on the development status and technological infrastructure of the countries. Especially today, the pandemic conditions of the whole world have increased the importance of distance education by directing education to the digital field.

Distance education, which has a greater place in educational environments with the involvement of technology in our lives, especially with the participation of computers in education supply, distribution of teaching materials through both print and electronic media (Moore, 1990; Moore et al., 2010), or according to Moore and Kearsley (2011) can be described as teaching and planned teaching activities in which communication is provided through technological equipment, in addition to traditional educational activities, and teaching takes place in different environments. In general, distance education is education and training activities where there is a regulated educational plan, the student and the teacher are in different places, but carried out through face-to-face meetings when necessary (Gunawardena \& McIsaac, 2001). Based on the definition expressed in this respect, it can be said that the most basic elements of distance education are the application of learning and teaching processes in different contexts (Yenilmez, Balbağ, \& Turgut, 2017). In addition, when the literature on distance education is reviewed, it is seen that distance education is used together with or synonymously with concepts such as "web-based education, learning via the Internet, and e-learning" (Turgut \& Yenilmez, 2011).

When we look at the position of distance education from the past to the present, it is seen that distance education is generally considered as an alternative to face-to-face education and this understanding still continues. Therefore, it is thought that distance education has not developed enough (Y1lmaz \& Düğnci, 2010). On the other hand, although it is assumed that distance education is as effective as face-to-face education today, it is known that its efficiency in educational environments is not as effective as face-to-face education. However, it would be beneficial for experts to draw attention to this point in order to at least create a good alternative to face-to-face education in order to develop distance education applications, increase scientific studies on this subject, and 
positively change the attitudes and behaviors of teachers and learners towards these trainings.

The main purpose of the research is to examine the views of education faculty students on distance education. In this context, answers were sought to the following questions.

Students' views on distance education;

a) What level is it?

b) Does it differ significantly according to the gender variable?

c) Does it differ significantly according to the grade variable?

d) Does it differ significantly according to the educational field variable?

e) Does it differ significantly according to which means of participating in distance education?

f) Does it differ significantly according to the variable of the number of people who continue distance education at home?

g) Does it differ significantly according to the Internet access type variable?

h) Does it differ significantly according to the study room variable?

i) Does it differ significantly according to the settlement variable?

j) Does it differ significantly according to the variable of preferring distance education or face-to-face education.

\section{Method}

\subsection{Research Model}

This research, which aims to examine the views of education faculty students on distance education, is a quantitative method with causal comparison model. "Research with causal comparison model is research that aims to determine the causes and consequences of differences between human groups without any intervention on conditions and participants" (Büyüköztürk et al., 2015: 15-16).

\subsection{Population and Sample}

The study population of the research consists of İnönü University Faculty of Education students. Within the scope of the research, stratified random sampling, which is one of the random sampling methods, was taken as the basis. While determining the stratum, the gender variable was determined as a criterion, and the percentage distribution in the population was $36.79 \%$ for boys and $63.21 \%$ for girls, and in the sample taken, the values were close to the gender distribution in the population. In addition, several methods were applied together in the stage of deciding on the sample size. Sample sizes determined according to different confidence levels and deviation amounts in the literature were examined (Büyüköztürk, Kılıç Çakmak, Akgün, Karadeniz, \& Demirel, 2015; Cohen, Manion, \& Morrison, 2007). As a result of the examinations, it was determined that the sample size should be 370, based on the confidence interval of ".95" and the amount of deviation for an average population size of 10,000 people (Büyüköztürk et al., 2015). The 
"power analysis" method, which is another sample size calculation method, was also used within the scope of the research. Although "power analysis" varies according to the type of analysis, it is used as one of the sample size calculation methods based on the .80 power level and the average effect size (Faul, Erdfelder, Lang, \& Buchner, 2007). Within the scope of this research, one-way anova test and pearson correlation test, which is one of the relationship tests, and the independent group $t$ test from causal comparison tests were used. In this context, as a result of the power analysis using the G*Power package program, it was seen that reaching a minimum sample number of 108 people would be sufficient for the analysis to be made.

Table 1: Introductory information about the sample group is given in

\begin{tabular}{|c|c|c|c|}
\hline \multicolumn{2}{|c|}{ Descriptive Statistics on Sampling } & & \\
\hline \multicolumn{2}{|c|}{ Variables } & Frequency (f) & $(\%)$ \\
\hline \multirow[t]{2}{*}{ Gender } & Female & 379 & 64.9 \\
\hline & Male & 205 & 35.1 \\
\hline \multirow[t]{4}{*}{ Grade } & 1st Grade & 97 & 16.6 \\
\hline & 2nd Grade & 358 & 61.3 \\
\hline & 3rd Grade & 81 & 13.9 \\
\hline & 4th Grade & 48 & 8.2 \\
\hline \multirow[t]{5}{*}{ Educational Field } & Quantitative & 62 & 10.6 \\
\hline & Verbal & 190 & 32.5 \\
\hline & Equally-weighted & 171 & 29.3 \\
\hline & $\begin{array}{l}\text { Gifted/Talented (art teaching-music } \\
\text { teaching- physical education and sports) }\end{array}$ & 99 & 17.0 \\
\hline & Foreign language & 44 & 7.5 \\
\hline \multirow{2}{*}{$\begin{array}{l}\text { How to Participate } \\
\text { in Distance Education }\end{array}$} & Computer & 307 & 52.6 \\
\hline & SmartPhone/Tablet Computer & 277 & 47.4 \\
\hline \multirow{4}{*}{$\begin{array}{l}\text { Number of People } \\
\text { Participating in } \\
\text { Distance Education }\end{array}$} & 1 Person & 180 & 30.8 \\
\hline & 2 Person & 168 & 28.8 \\
\hline & 3 Person & 151 & 25.9 \\
\hline & 4 and More & 85 & 14.6 \\
\hline \multirow[t]{2}{*}{ Internet Access Type } & Fixed(Home) Internet & 428 & 72.8 \\
\hline & Mobile Internet & 159 & 27.2 \\
\hline \multirow[t]{2}{*}{ Study room } & Available & 366 & 62.7 \\
\hline & Not available & 218 & 37.3 \\
\hline \multirow[t]{3}{*}{ Residential area } & Center/ Central District & 395 & 67.6 \\
\hline & District & 109 & 18.7 \\
\hline & Rural & 80 & 13.7 \\
\hline \multirow{2}{*}{$\begin{array}{l}\text { Prefer Face-to-face Education } \\
\text { or Distance Education }\end{array}$} & Face to face education & 102 & 17.5 \\
\hline & Distance Learning & 482 & 82.5 \\
\hline
\end{tabular}

In Table 1, the personal characteristics of the education faculty students participating in the research are given. Accordingly, while $64.9 \%$ of the sample consists of female students, $35.1 \%$ consists of male students. In terms of the class variable, it is seen that the largest group of the sample is the students in the 2 nd grade with $61.3 \%$, while the smallest group is the students in the 4 th grade with $8.2 \%$. In terms of the educational field variable, 
it was stated that the largest group was the students studying in the field with verbal input with $32.5 \%$, and the smallest group was the students studying in the field with foreign language input with $7.5 \% .52 .6 \%$ of the sample stated that they participated in distance education over the computer, and $47.4 \%$ via the phone. Considering the variable of the number of people participating in distance education at home, it is seen that the largest group is 1 person with $30.8 \%$, and the smallest group is the group with 4 or more people with $14.6 \%$. In terms of internet access type variable, $72.8 \%$ of the participants stated that they participated in distance education via fixed (home) internet and 27.2\% via mobile internet. $62.7 \%$ of the education faculty students who participated in the research stated that they had a study room, and $37.3 \%$ stated that they did not have a study room. $67.6 \%$ of the participants live in the center or central district, $18.7 \%$ in the district and $13.7 \%$ in the village. Finally, $17.5 \%$ of the sample prefer face-to-face education and $82.5 \%$ prefer distance education.

\subsection{Data Collection Tools}

The first part of the measurement tool used in the research consists of the demographic information of the participants, developed by the researchers. In the second part of the study, the "Distance Education Evaluation Scale" developed by Özkul, Kırnık, Dönük, Altunhan and Altunkaynak (2021) was used.

\subsubsection{Distance Education Evaluation Scale}

The scale was developed by Özkul, Kırnık, Dönük, Altunhan, and Altunkaynak (2021). Opinions were received from 1 faculty member and 3 experts who are field experts during the item identification phase. A pre-application was made with an item pool consisting of 26 items. The scale items are in a 5-point Likert type and the degree of agreement of the participants with the items was classified. The specially developed distance education evaluation scale was applied to 600 teachers and school administrators. The construct validity, content validity, item-total correlation coefficient, Cronbach Alpha coefficient, test-retest correlation coefficient were determined. As a result of the analyzes made, the distance education evaluation scale consisted of 15 items and two dimensions. The item-total correlation coefficients of the dimensions are between ".55" and ".87", and the internal consistency (Cronbach Alpha) coefficient is between ".96" and ".89". It was stated that as the scores obtained from the scale increased, distance education was perceived positively, and as it decreased, it was perceived negatively. Within the scope of this research, the internal consistency (Cronbach Alpha) coefficient was determined as .93. Demographic Information Questionnaire: The demographic information questionnaire, in which the participants' information such as "gender, class, area, the means by which they participated in distance education, the number of people who participated in distance education at home, the type of internet access, study room, residence, preferring distance education or face-to-face education" were collected and developed by the researchers. 


\subsection{Data Analysis}

The normality distribution of the data obtained in the study was examined and it was seen that there was no wrong or incompletely filled scale. Analyzes were made on 584 scales. The obtained data were subjected to independent groups T, One Way ANOVA and descriptive statistics tests. The analyzes of the data collected within the scope of the research were made using the SPSS 24.0 package program.

\section{Results}

The first sub-title of the first sub-problem of the research is "What is the level of students' views on distance education?" expressed as. The descriptive statistics results obtained for this purpose are given in Table 2.

Table 2: Level of Students' Views on Distance Education

\begin{tabular}{|l|c|c|c|c|}
\hline Dimensions & $\mathbf{N}$ & $\mathbf{M}$ & SD & Level \\
\hline Distance Learning & 584 & 2.69 & .817 & Moderately Agree \\
\hline
\end{tabular}

Looking at Table 2, it is seen that the average score of the participants is 2.69 , and this score is at the level of "Moderate Agree" on the scale.

\subsection{Findings regarding the gender variable}

The second sub-title of the first sub-problem of the research is "Do students' views on distance education differ significantly according to the gender variable?" expressed as. For this purpose, T-Test was conducted on Independent Groups. The results are in Table 3.

Table 3: T-Test Results Regarding Whether Students' Opinions on Distance Education Differ Significantly According to Gender Variable

\begin{tabular}{|l|l|c|c|c|c|c|c|}
\hline & Gender & $\mathbf{N}$ & $\mathbf{M}$ & SD & df & $\mathbf{t}$ & $\mathbf{p}$ \\
\hline \multirow{2}{*}{ Distance Learning } & Female & 379 & 40.80 & 12.14 & \multirow{2}{*}{582} & \multirow{2}{*}{.988} & \multirow{2}{*}{.323} \\
\cline { 2 - 7 } & Male & 205 & 39.75 & 12.49 & & & \\
\hline
\end{tabular}

Looking at the values in Table 3; students' views on distance education do not differ statistically significantly according to their gender $(t=0.988, \mathrm{p}<.05)$.

\subsection{Findings regarding the class variable}

The third sub-title of the first sub-problem of the research is "Do students' views on distance education differ significantly according to the class variable?" expressed as. For this purpose, One-Way ANOVA Test was conducted. The results are in Table 4. 
Table 4: One-Way ANOVA Test Results on Whether Students'

Views on Distance Education Differ Significantly According to Class Variable

\begin{tabular}{|l|l|c|c|c|c|c|c|c|c|c|}
\hline & Grade & $\mathbf{N}$ & $\mathbf{M}$ & SD & $\begin{array}{c}\text { Source of } \\
\text { Variance }\end{array}$ & $\begin{array}{c}\text { Sum of } \\
\text { Squares }\end{array}$ & $\mathbf{d f}$ & $\begin{array}{c}\text { Mean of } \\
\text { Squares. }\end{array}$ & $\mathbf{F}$ & $\mathbf{p}$ \\
\hline \multirow{4}{*}{$\begin{array}{l}\text { Distance } \\
\text { Education }\end{array}$} & 1. Grade & 97 & 41.00 & 11.97 & Intergroups & 138.1 & 3 & 46.06 & .305 & .822 \\
\cline { 2 - 12 } & 2. Grade & 358 & 40.59 & 12.19 & In Groups & 87577.2 & 580 & 150.99 & & \\
\cline { 2 - 12 } & 3. Grade & 81 & 39.46 & 12.74 & Total & 87715.3 & 583 & & & \\
\cline { 2 - 11 } & 4. Grade & 48 & 39.77 & 12.87 & & & & & & \\
\hline Total & & 584 & 40.43 & 12.26 & & & & & & \\
\hline
\end{tabular}

Looking at the values in Table 4; it is seen that students' views on distance education do not differ statistically significantly according to the class variable $(\mathrm{F}=0.305$ and $\mathrm{p}<.05)$.

\subsection{Findings regarding the educational field variable}

The fourth sub-title of the first sub-problem of the research is "Do students' views on distance education differ significantly according to the educational field variable?" expressed as. For this purpose, One-Way ANOVA Test was conducted. The results are in Table 5.

Table 5: One-Way ANOVA Test Results on Whether Students' Views on Distance Education Differ Significantly According to Educational Field Variable

\begin{tabular}{|c|c|c|c|c|c|c|c|c|c|c|c|}
\hline Edu.Field & $\mathbf{N}$ & $\mathbf{M}$ & SD & $\begin{array}{l}\text { Source of } \\
\text { Variance }\end{array}$ & $\begin{array}{l}\text { Sum of } \\
\text { Squares }\end{array}$ & sd & $\begin{array}{l}\text { Mean of } \\
\text { Squares }\end{array}$ & $F$ & $p$ & $\begin{array}{c}\text { Difference } \\
\text { (Sidak) }\end{array}$ & $\begin{array}{c}\text { Eta } \\
\text { square } \\
\left(\eta^{2}\right)\end{array}$ \\
\hline Quantitative & 80 & 41.20 & 11.12 & Intergroups & 3350.1 & 4 & 837.5 & \multirow[t]{3}{*}{5.748} & \multirow[t]{3}{*}{.000} & \multirow{3}{*}{$\begin{array}{c}1-4 \\
2-4,3-4\end{array}$} & \multirow[t]{3}{*}{.039} \\
\hline Verbal & 190 & 42.15 & 12.58 & In Groups & 84365.8 & 579 & 145.7 & & & & \\
\hline $\begin{array}{l}\text { Equally- } \\
\text { weighted }\end{array}$ & 171 & 41.00 & 11.11 & Total & 87715.4 & 583 & & & & & \\
\hline $\begin{array}{l}\text { Gifted/ } \\
\text { talented }\end{array}$ & 99 & 35.24 & 13.63 & & & & & & & & \\
\hline \multirow[t]{2}{*}{$\begin{array}{l}\text { Foreign } \\
\text { language }\end{array}$} & 44 & 41.07 & 11.31 & & & & & & & & \\
\hline & 584 & 40.34 & 12.27 & & & & & & & & \\
\hline
\end{tabular}

Looking at the values in Table 5; it is seen that there is a statistically significant difference between students' views on distance education and the educational field variable $(\mathrm{F}=5.748$ and $\mathrm{p}<.05)$. Considering the average scores, the evaluation level of distance education is the highest in the departments that take students with a verbal score with $\mathrm{M}=42.15$, the second place is the department that takes students with a foreign language score with $M=41.07$, and the lowest is the student with a gifted/talented (art teachingmusic teaching- physical education and sports) score with $M=35.24$. seen in the students of the department. According to the Sidak test conducted to find the source of the difference, the difference between the departments that admit students with special talent points and departments that accept students with quantitative, verbal and equal weight scores, and the students of the department that accept students with gifted/talented points. It is seen that the effect size calculated as a result of the test $(\eta 2=.039)$ is closer to the medium level. 


\subsection{Findings on the variable of participating in distance education with which tool}

The fifth sub-title of the first sub-problem of the research is "Do students' views on distance education differ significantly according to the method of participating in distance education?" expressed as. For this purpose, Independent Groups T-Test was conducted. The results are in Table 6.

Table 6: Independent Group T-Test Results on Whether Students' Opinions on Distance Education Differ According to the Variable of Participating in Distance Education

\begin{tabular}{|l|l|c|c|c|c|c|c|c|}
\hline & Tool & $\mathbf{N}$ & $\mathbf{M}$ & SD & sdf & $\mathbf{t}$ & $\mathbf{p}$ & Cohen's d \\
\hline \multirow{2}{*}{ Distance Education } & Computer & 307 & 43.30 & 11.61 & \multirow{2}{*}{582} & \multirow{2}{*}{6.144} & \multirow{2}{*}{.000} & \multirow{2}{*}{.51} \\
\cline { 2 - 6 } & Smart Phone & 277 & 37.25 & 12.21 & & & \\
\hline
\end{tabular}

Looking at the values in Table 6; it is seen that students' views on distance education differ statistically according to the means by which they participate in distance education $(t=-6.144, p<.05)$. When the average scores are examined, it is seen that the average scores of those who participate in distance education by computer $(M=43.30)$ are higher than the average scores of those who participate by phone $(M=37.25)$. Considering the effect size $(\mathrm{d}=.51)$, it can be said that this difference is at a moderate level.

\subsection{Findings on the variable of the number of people continuing distance education at home}

The sixth sub-title of the first sub-problem of the research is "Do students' views on distance education differ significantly according to the variable of the number of people participating in distance education at home?" expressed as. For this purpose, One-Way ANOVA Test was conducted. The results are in Table 7.

Table 7: One-Way ANOVA Test Results on Whether Students' Views on Distance Education Differ Significantly According to the Variable

of the Number of People Attending Distance Education at Home

\begin{tabular}{|c|c|c|c|c|c|c|c|c|c|c|c|c|}
\hline & Person & $\mathbf{N}$ & $\mathbf{M}$ & SD & $\begin{array}{l}\text { Source of } \\
\text { Variance }\end{array}$ & $\begin{array}{l}\text { Sum of } \\
\text { Squares }\end{array}$ & $\mathrm{df}$ & $\begin{array}{l}\text { Mean of } \\
\text { Squares. }\end{array}$ & F & $p$ & $\begin{array}{c}\text { Difference } \\
\text { (Sidak) }\end{array}$ & $\begin{array}{c}\text { Eta } \\
\text { square } \\
\left(\eta^{2}\right)\end{array}$ \\
\hline \multirow{4}{*}{$\begin{array}{l}\text { Distance } \\
\text { Learning }\end{array}$} & 1 Per. & 180 & 41.87 & 12.67 & Intergroups & 1327.1 & 3 & 442.3 & \multirow[t]{3}{*}{2.970} & \multirow[t]{3}{*}{.031} & \multirow[t]{3}{*}{$1-4$} & \multirow[t]{3}{*}{.015} \\
\hline & 2 Per. & 168 & 39.83 & 11.59 & In groups & 86388.3 & 580 & 148.9 & & & & \\
\hline & 3 Per. & 151 & 41.15 & 12.13 & Total & 87715.3 & 583 & & & & & \\
\hline & $\begin{array}{l}4 \text { and } \\
\text { more }\end{array}$ & 85 & 37.33 & 12.49 & & & & & & & & \\
\hline Total & & 584 & 40.43 & 12.26 & & & & & & & & \\
\hline
\end{tabular}

Looking at the values in Table 7; It is seen that there is a statistically significant difference between the students' views on distance education and the variable of the number of people participating in distance education at home $(\mathrm{F}=2.970$ and $\mathrm{p}<.05)$. Considering the average scores, the evaluation level of distance education is the highest with $\mathrm{M}=41.87$ points, the number of people participating in distance education at home is one, the second is with $M=41.15$ points, the number of people participating in distance education at home is two, and the lowest is with $\mathrm{M}=37.33$ points. It is seen that there are students with four or more people participating in distance education at home. According to the 
Sidak test performed to find the source of the difference, the difference emerged between the group with one and four or more participants in distance education at home, and in favor of the group with one. It is seen that the effect size calculated as a result of the test $(\eta 2=.015)$ is small.

\subsection{Findings on the type of internet access variable}

The seventh sub-title of the first sub-problem of the research is "Do students' views on distance education differ significantly according to the variable of internet access type?" expressed as. For this purpose, Independent Groups T-Test was conducted. The results are in Table 8.

Table 8: Independent Group T-Test Results on Whether Students' Views on Distance Education Differ Significantly According to Internet Access Type Variable

\begin{tabular}{|l|l|c|c|c|c|c|c|c|}
\hline & Internet Type & $\mathbf{N}$ & $\mathbf{M}$ & SD & df & $\mathbf{t}$ & $\mathbf{p}$ & Cohen's d \\
\hline \multirow{2}{*}{ Distance Learning } & Fixed (home) & 425 & 42.50 & 11.42 & \multirow{2}{*}{582} & \multirow{2}{*}{6.907} & \multirow{2}{*}{.000} & \multirow{2}{*}{.64} \\
\cline { 2 - 9 } & Mobile & 159 & 34.91 & 12.76 & & & \\
\hline
\end{tabular}

Looking at the values in Table 8; It is seen that students' views on distance education differ statistically according to the internet access type variable $(t=-6.907, p<.05)$. Considering the average scores, it is seen that the average scores of those who participate in distance education with fixed (home) internet $(\mathrm{M}=42.50)$ are higher than the average scores of those who participate with mobile internet $(\mathrm{M}=34.91)$. Considering the effect size $(\mathrm{d}=.64)$, it can be said that this difference is between medium level and large level.

\subsection{Findings on the study room variable}

The eighth sub-title of the first sub-problem of the research is "Do students' views on distance education differ significantly according to the study room variable?" expressed as. For this purpose, Independent Groups T-Test was conducted. The results are in Table 9.

Table 9: Independent Group T-Test Results on Whether Students' Views on Distance Education Differ Significantly According to the Study Room Variable

\begin{tabular}{|l|l|c|c|c|c|c|c|c|}
\hline & Study room & $\mathbf{N}$ & $\mathbf{M}$ & $\mathbf{S D}$ & $\mathbf{d f}$ & $\mathbf{t}$ & $\mathbf{p}$ & Cohen's d \\
\hline \multirow{2}{*}{ Distance Learning } & Available & 366 & 42.62 & 11.41 & \multirow{2}{*}{582} & \multirow{2}{*}{5.734} & .000 & \multirow{2}{*}{0.49} \\
\cline { 2 - 6 } & Unavailable & 218 & 36.76 & 12.79 & & & \\
\hline
\end{tabular}

Looking at the values in Table 9; students' views on distance education differ statistically significantly according to the study room variable $(t=-5.734, p<.05)$. Considering the average scores, it is seen that the average scores of those who have their own study room $(\mathrm{M}=42.62)$ are higher than those who do not ( $X$ olmayan=36.76). Considering the effect size $(d=.49)$, it can be said that this difference is moderate. 


\subsection{Findings on the settlement variable}

The ninth sub-title of the first sub-problem of the research is "Do students' views on distance education differ significantly according to the place of residence variable?" expressed as. For this purpose, One-Way ANOVA Test was conducted. The results are in Table 10.

Table 10: One-Way ANOVA Test Results on Whether Students' Views on Distance Education Differ Significantly According to the Variable of Place of Residence

\begin{tabular}{|c|c|c|c|c|c|c|c|c|c|c|c|c|}
\hline & $\begin{array}{l}\text { Residential } \\
\text { area }\end{array}$ & $\mathbf{N}$ & M & SD & $\begin{array}{l}\text { Source of } \\
\text { Variance }\end{array}$ & $\begin{array}{l}\text { Sum of } \\
\text { Squares }\end{array}$ & df & $\begin{array}{l}\text { Mean of } \\
\text { Squares }\end{array}$ & F & p & $\begin{array}{c}\text { Diffrence } \\
\text { (Sidak) }\end{array}$ & $\begin{array}{c}\text { Eta } \\
\text { square } \\
\left(\eta^{2}\right)\end{array}$ \\
\hline \multirow{3}{*}{$\begin{array}{l}\text { Distance } \\
\text { Learning }\end{array}$} & $\begin{array}{l}\text { Center/central } \\
\text { district }\end{array}$ & 395 & 41.58 & 12.06 & Gruplararası & 2256.7 & 2 & 1128.3 & \multirow[t]{3}{*}{7.671} & \multirow[t]{3}{*}{.001 } & \multirow[t]{3}{*}{$1-3$} & \multirow[t]{3}{*}{.025} \\
\hline & District & 109 & 39.61 & 12.54 & Gruplariçi & 85458.6 & 581 & 147.1 & & & & \\
\hline & Rural & 80 & 35.88 & 11.87 & Toplam & 87715.3 & 583 & & & & & \\
\hline Total & & 584 & 40.43 & 12.26 & & & & & & & & \\
\hline
\end{tabular}

Looking at the values in Table 10; it is seen that there is a statistically significant difference between students' views on distance education and the variable of residence $(\mathrm{F}=7.671$ and $\mathrm{p}<.05)$. Considering the average scores, it is seen that the evaluation level of distance education is highest among those living in the center/central district with $M=41.58$ points, and the lowest among those living in villages with $M=37.33$ points. According to the Sidak test performed to find the source of the difference, the difference emerged between the group whose settlement is the center/central district and the group with the village, and in favor of those living in the center/central district. It is seen that the effect size calculated as a result of the test $(\eta 2=.025)$ is small.

\subsection{Findings on the variable of preferring distance education or face-to-face education}

The tenth sub-title of the first sub-problem of the research is "Do students' views on distance education differ significantly according to the variable of preferring distance education or face-to-face education?" expressed as. For this purpose, Independent Groups T-Test was conducted. The results are given in Table 11.

Table 11: Independent Group T-Test Results Regarding Whether Students'

Opinions on Distance Education Differentiate Significantly According to the Variable of Preferring Distance Education or Face-to-Face Education

\begin{tabular}{|l|l|c|c|c|c|c|c|c|}
\hline & Preference & $\mathbf{N}$ & $\mathbf{M}$ & SD & df & $\mathbf{t}$ & $\mathbf{p}$ & Cohen's d \\
\hline \multirow{2}{*}{ Distance Learning } & Distance Learning & 482 & 53.09 & 11.41 & \multirow{2}{*}{582} & \multirow{2}{*}{-12.99} & \multirow{2}{*}{.000} & \multirow{2}{*}{1.42} \\
\cline { 2 - 9 } & Face to face education & 102 & 37.76 & 10.67 & & & \\
\hline
\end{tabular}

Looking at the values in Table 11; students' views on distance education differ significantly according to the variable of preferring distance education or face-to-face education ( $t=-12.997, \mathrm{p}<.05)$. Considering the average scores, it is seen that the average scores of those who prefer distance education $(\mathrm{M}=53.09)$ are higher than the average scores of those who prefer face-to-face education $(M=37.76)$. Considering the effect size $(\mathrm{d}=1.42)$, it can be said that this difference is quite large. 


\section{Discussion, Conclusion and Recommendations}

Within the scope of the research, it was aimed to examine the views of teacher candidates on distance education. In the light of the findings obtained, conclusions and recommendations were developed.

It was concluded that the views of the participants on distance education were at the level of "I agree at a moderate level". In the studies conducted in the literature on the distance education process, it has been stated that teacher candidates do not have sufficient knowledge about distance education and the number of teacher candidates participating in distance education is limited (Ateş \& Altun, 2008). In addition, it was stated that face-to-face education was preferred compared to the distance education process with the first outbreak of the Covid-19 epidemic (Akgül, 2021).

In this context, it can be said that both educators and students adapt to distance education in terms of technique and learning process.

It was concluded that teacher candidates' views on distance education did not differ statistically significantly according to their gender and grade levels. This result is consistent with the results of the studies conducted by Ateş and Altun (2008) and Barış (2015). According to these results, it can be expressed as an expected result when it is considered that the prospective teachers are close to each other in age and that distance education requires certain skills. Pre-service teachers' views on distance education differed according to the field variable. The difference is between departments that accept students with special talent points and departments that accept students with numerical, verbal and equal weight scores (in favor). Studies show that especially the distance education process is applied theoretically and that theory-based courses are given priority. In this context, it can be stated that the departments that require more practice and are skill-based remain in the background in the distance education process. In addition, an important problem faced by students in the distance education method in applied courses is the supply of materials. Due to the curfew imposed by the Covid-19 epidemic measures, students' access to course materials was adversely affected (Kahraman, 2020). It is seen that the average scores of the teacher candidates who participated in distance education by computer are higher than the average scores of those who participated in the distance education by phone. According to this result, this difference is due to many reasons such as actively participating in the lessons in the distance education process, expressing their views in writing, wanting to answer the questions in written as well as verbally, wanting to watch presentations and lessons on a larger screen, and computers being more useful. can be expressed. According to Engin, Tösden, and Kaya (2010), the resources that students seek will be instantly available thanks to computers and will be used when necessary.Students will be able to create a unique knowledge library by archiving, filing and categorizing existing information. Since the programs prepared in the computer environment are diversified by considering different types of students, they will also provide convenience and privileges for students with different types and levels of intelligence. 
It has been concluded that students' views on distance education differ significantly according to the variable of the number of people participating in distance education at home. This difference is in favor of the group with one to four or more people participating in distance education at home and in favor of the group with one. This result is expected. In this result; It can be stated that it is caused by the problems arising from the conflict of classes and internet use as much as the number of computers, tablets and phones at home. In addition, in distance education, it is important for students to enter classes comfortably and to have their own rooms. This situation can affect negatively the families with a large number of family members. The results of the research show that the average scores of those who participate in distance education with fixed (home) internet are higher than the average scores of those who participate with mobile internet. It is a fact that active internet use has increased in the distance education process and more internet is needed as a quota. In this context, the advantage of fixed (home) internet in this regard has been effective in this result. Research result; shows that the average scores of students who have their own study room during the distance education process are higher than those who do not have a study room. This result revealed the importance of students focusing on online lessons and creating a comfortable environment for themselves with the distance education process. In this context, it can be said that they need an independent room to follow the lessons and actively participate in the lessons. In addition, it is also important for time management that the computers and tablets they use are constantly ready for use in their rooms so that they do not prepare the technological infrastructure every time. The results of the research show that there is a statistically significant difference between the students' views on distance education and the variable of the place of residence. The level of evaluation regarding distance education is high for those living in the center/central district, and low for those living in the village. The most problematic areas in the distance education process are the inadequacy of the internet infrastructure and the lack of internet infrastructure in rural areas. Due to the Covid-19 epidemic, it is likely that the rapid transition to the distance education model without the necessary evaluations and examinations will cause some negativities or disruptions in practice (Kaya, 2020). It is seen that many different problems are pointed out even in the distance education applications that are applied in a planned manner (Kirmacı \& Acar, 2018).The result of the research shows that the students differ statistically significantly according to the variable of preferring distance education or face-to-face education. Interestingly, students preferred distance education to face-to-face education. In the emergence of this result; It can be said that the reasons such as distance education being more student-centered, providing equal opportunities in education, providing education opportunities to people who are deprived of the right to education due to health problems, covering a large audience, and removing the barrier of place and time are effective. While DeNeui and Dodge (2006) and Horspol and Lange (2012) consider it an advantage that distance education is independent of time and environment; Horspol and Lange (2012) also stated that it saves time in terms of going to and from home and school, and provides ease of 
learning spatially by providing easy communication with online platforms. Based on the results of the research, it will be useful to plan and put on the agenda the distance education process, especially for the practice-oriented courses, in the coming years. In order to make the distance education process more efficient and effective, some studies can be carried out by the authorities directly via satellite or by strengthening the networks without the need for infrastructure. In addition, by strengthening the internet infrastructure used in schools affiliated to the Ministry of National Education for all students living in rural areas, it can be made available to university students as well.

\section{Conflict of Interest Statement}

The authors declare no conflicts of interests.

\section{About the Authors}

Res. Asst. Fatih Kaya works at İnönü University Faculty of Education, Department of Social Studies Education, I am doing my doctorate in values education.

Dr. Ramazan Özkul works as a Mathematics teacher at the Ministry of National Education. He completed his PhD in Educational Administration in Inonu University, Faculty of Education, Department of Educational Sciences in 2021.

Dr. Metin Kurbaç completed his PhD in Educational Administration in Inonu University, Faculty of Education, Department of Educational Sciences in 2019. He is a faculty member in the Department of Measurement and Evaluation at the same university.

\section{References}

Akgül, G. (2021). Sosyal bilgiler öğretmenlerinin, ortaokul öğrencilerinin ve öğrenci velilerinin pandemi sürecindeki uzaktan eğitime ilişkin görüşleri. [Opinions of social studies teachers, secondary school students and parents of students on distance education in the pandemic process] (Yayımlanmamış Yüksek Lisans Tezi). Uşak Üniversitesi Lisansüstü Eğitim Enstitüsü, Sosyal Bilgiler Eğitimi Bilim Dalı.

Ateş, A. ve Altun, E. (2008). Bilgisayar öğretmeni adaylarının uzaktan eğitime yönelik tutumlarının çeşitli değişkenler açısından incelenmesi. [Examining the attitudes of computer teacher candidates towards distance education in terms of various variables] Gazi Eğitim Fakültesi Dergisi, 28 (3), 125-145.

Barış, M. F. (2015). Üniversite öğrencilerinin uzaktan öğretime yönelik tutumlarının incelenmesi: Namık Kemal Üniversitesi örneği. [Examining the attitudes of university students towards distance education: The case of Namik Kemal University] Sakarya University Journal of Education, 5(2), 36-46. Doi:10.19126/suje.38758

Büyüköztürk, Ş., Kılıç Çakmak, E., Akgün, Ö. E., Karadeniz, Ş. \& Demirel, F. (2015). Bilimsel araştırma yöntemleri. [Scientific research methods] Pegem Yayınları. 
Cohen, L., Manion, L. \& Morrison, K. (2007). Observation. Research Methods in Education, 6, 396-412.

DeNeui, D., \& Dodge, T. (2006). Asynchronous Learning Networks and Student Outcomes: The Utility of Online Learning Components in Hybrid Courses. Journal of Instructional Psychology, 33(4), 256-259.

Engin, A. O., Tösden, R. ve Kaya, M. D. (2010). Bilgisayar destekli eğitim. [Computer aided education] Sosyal Bilimler Enstitüsü Dergisi, 5, 69-80.

Faul, F., Erdfeler, E., Lang, A. G. \& Buchner, A. (2007). G*Power 3: A flexible statistical power analysis program for the social, behavioral, and biomedical sciences. Behavior Research Methods, 39(2), 175-191.

Gunawardena, C. N., \& McIsaac, M. S. (2001). Distance education. In D.H. Jonasses (Ed.) Handbook of research for educational communications and technology (pp. 355395). US: Lawrence Earlbaum.

Horspool, A., \& Lange, C. (2012). Applying the scholarship of teaching and learning: Student perceptions, behaviours and success online and face-to-face. Assessment $\mathcal{E}$ Evaluation in Higher Education, 37(1), 73-88.

Kahraman, M. E. (2020). Covıd-19 salgınının uygulamalı derslere etkisi ve bu derslerin uzaktan eğitimle yürütülmesi: Temel tasarım dersi örneği. [The effect of the Covid-19 epidemic on applied courses and the conduct of these courses with distance education: An example of a basic design course] IMÜ Sanat Tasarm ve Mimarlık Fakültesi Dergisi, 6(1), 44-56. Doi: https://doi.org/10.46641/ medeniyetsanat.741737

Kaya, S. (2020). Zorunlu uzaktan eğitimde karşılaşılan sorunlar: öğretim elemanı ve öğrenci görüşleri. [Problems encountered in compulsory distance education: views of instructors and students] EJER Congress 2020 Bildiri Özetleri Kitab1.

Kırmacı, Ö., \& Acar, S. (2018). Kampüs öğrencilerinin eşzamanlı uzaktan eğitimde karşılaştıkları sorunlar. [The problems faced by campus students in simultaneous distance education] Journal of Theory and Practice in Education, 14(3), 276- 291. doi:10.17244/eku.378138

Moore, J. L., Dickson-Deane, C., ve Galyen, K. (2010). e-Learning, online learning, and distance learning environments: Are they the same?. The Internet and Higher Education, 14(2), 129-135.

Moore, M. G. (1990). Background and overview of contemporary American distance education. Contemporary issues in American distance education(pp. xii-xxvi). Pergamon Press.

Moore, M. ve Kearsley, G. (2011). Distance education: A system view of online learning (Third Edition). Belmont, Calif: Wadsworth Pub. Co.

Özkul, R., Kırnık D., Dönük, O., Altunhan, Y., \& Altunkaynak, Y. (2020). Uzaktan eğitim uygulamalarına ilişkin öğretmen görüşleri: Ölçek çalışması. [Teachers' views on distance education practices: A scale study] Turkish Studies, 15(8), 3655-3667. https://dx.doi.org/10.7827/TurkishStudies.46557 
Telef, B. B. (2013). Psikolojik iyi oluş ölçeği: Türkçeye uyarlama, geçerlik ve güvenirlik çalışması. [Psychological well-being scale: Turkish adaptation, validity and reliability study] Hacettepe Üniversitesi Ĕ̆itim Fakültesi Dergisi, 28(3), 374-384.

Turgut, M. ve Yenilmez, K. (2011). İlköğretimde web tabanlı matematik eğitimine ilişkin lisansüstü öğrencilerin görüşleri. [Postgraduate students' views on web-based mathematics education in primary education] Turkish Journal of Computer and Mathematics Education, 2(2), 121-139.

Yenilmez, K., Turğut, M., \& Balbağ, M. Z. (2017). Öğretmen adaylarının uzaktan eğitime yönelik tutumlarının bazı değişkenler açısından incelenmesi. [Examination of teacher candidates' attitudes towards distance education in terms of some variables] Erzincan Üniversitesi Ĕ̆itim Fakültesi Dergisi, 19(2), 91-107.

Yılmaz, H., Düğenci, M. (2010). Hizmet içi eğitime farklı bir yaklaşım: e-hizmet içi eğitim, Muğla üniversitesi. [A different approach to in-service training: e-in-service training, Muğla University] Akademik Bilişim Konferansı Bildirileri. 67-74. 

to copy, distribute, transmit or adapt the article content, providing a proper, prominent and unambiguous attribution to the authors in a manner that makes clear that the materials are being reused under permission of a Creative Commons License. Views, opinions and conclusions expressed in this research article are views, opinions and conclusions of the author(s). Open Access Publishing Group and European Journal of Education Studies shall not be responsible or answerable for any loss, damage or liability caused in relation to/arising out of conflicts of interest, copyright violations and inappropriate or inaccurate use of any kind content related or integrated into the research work. All the published works are meeting the Open Access Publishing requirements and can be freely accessed, shared, modified, distributed and used in educational, commercial and non-commercial purposes under a Creative Commons Attribution 4.0 International License (CC BY 4.0). 